\title{
Correction to: Effect of Exposure Time on Corrosion Behavior of Carbon Steel in Presence of Shewanella RCRI7 Bacteria
}

\author{
Hadi Adelkhani ${ }^{1} \cdot$ Mohammad Jafar Shirdoust $^{2} \cdot$ Faezeh Fatemi $^{1} \cdot$ Hassan Jafari ${ }^{3}$
}

Published online: 17 January 2022

(c) Springer Nature Switzerland AG 2022

\section{Correction to: Journal of Bio- and Tribo-Corrosion https://doi.org/10.1007/s40735-021-00602-8}

Hassan Jafari's given name and affiliation are correct as reflected here. The original article was corrected.

Publisher's Note Springer Nature remains neutral with regard to jurisdictional claims in published maps and institutional affiliations.

The original article can be found online at https://doi.org/10.1007/ s40735-021-00602-8.

Hadi Adelkhani

adelkhani@hotmail.com; hadelkhani@aeoi.org.ir

1 Nuclear Fuel Cycle Research School, Nuclear Science and Technology Research Institute, Tehran, Iran

2 Department of Metallurgy and Materials Science, Shahid Rajaee University, Tehran, Iran

3 Materials Engineering Department, Shahid Rajaee Teacher Training University, Tehran, Iran 